\title{
Photodynamic Therapy Overcoming the Hypoxia Microenvironment in Tumor Tissues
}

\author{
Zheng Ruan* \\ Department of Chemical Physics, University of Science and Technology of China, China
}

Submission: May 14, 2018; Published: June 18, 2018

*Corresponding author: Zheng Ruan, Department of Chemical Physics, University of Science and Technology of China, China, Email: rzchn@mail.ustc.edu.cn

Keywords: Photodynamic therapy; Bladder cancer; Boron-dipyrromethene

Abbreviations: PDT: Photodynamic Therapy; PS: Photo Sensitizers; ROS: Reactive Oxygen Species; ISC: Intersystem’s Crossing

\section{Opinion}

Photodynamic therapy (PDT) has been broadly exploited as an substitute therapeutic for cancer treatment since it was first allowed for the treatment of bladder cancer in 1993 [1]. It depends on the ability of photo sensitizers (PS) to transfer energy from light irradiation to tumor-dissolved oxygen $\left(\mathrm{O}_{2}\right)$ to produce cytotoxic reactive oxygen species (ROS) for killing cells $[2,3]$. In the presence of molecular oxygen $\left(\mathrm{O}_{2}\right)$, PS photo activation results in the creation of reactive oxygen species (ROS) like singlet oxygen $\left(\mathrm{O}_{2}\right)$ and damage to tumor tissues. Compared with other traditional cancer therapies such as chemotherapy, PDT is invasive and negligibly toxic [4]. Since treatment occurs only where light is delivered, it avoids systematic treatment. Moreover, PDT can cause an inflammation immune response and enlargement of anti-tumor immune surveillance. These primary and secondary reaction mechanisms provide great inspiration for developing PDT for cancer treatment [5].

First of all, the high efficiency of the PDT agent itself should be emphasized. The photo sensitizer with higher singlet oxygen quantum yield could yield more ROS after the same irradiation condition. Many dyes obtained from natural or synthetic sources with high intersystem's crossing (ISC) which have been used for singlet oxygen reactions. The heavy atom effect has been a valuable chemical approach to increase ISC in several molecules including BODIPY chromophores [6]. Regarding of that, we have designed and synthesized a kind of boron-dipyrromethene derivative with bromine substituted (BDP-Br) which has shown excellent ability of generating reactive oxygen species (ROS) upon irradiation for PDT. Then, a simply PE Gylated BDP-Br (PEG-BDP) as some kind of macro photo sensitizer was prepared which has shown superior cellular uptake ability and high efficiency of imaging and curing to PDT therapy in vitro and in vivo [7].
However, the direct therapeutic effect of PDT depend on ROS such as singlet oxygen $\left(\mathrm{O}_{2}\right)$ which has been still depend on oxygen supply in tissues [8]. Thus, a major barrier in photodynamic therapy (PDT) for higher efficiency is hypoxia environment in tumor area and PDT-induced incessant consumption of oxygen. Owing to the abnormal new blood vessels and slack blood flow in tumor tissues, there comes inequity between oxygen supply and cancer cell oxygen consumption. Reported here to overcome this problem, we had designed and synthesized an oxygen self-sufficient nanoparticles by loading BODIPY into a waterdispersible fluorinated polypeptide drug delivery platform for high efficiency PDT [9]. Since the ability of higher oxygen capacity and $\mathrm{O}_{2}$ lifetime enhancement of perfluorocarbon, comparing with non-fluorinated polymeric platform, the whole PDT agent confirmed higher oxygen uptake and enhanced singlet oxygen production, showing the prospective to increase the PDT efficacy in hypoxic tumor environments after irradiation. Although the oxygen content in tumor area remains inadequate during PDT, enough $\mathrm{O}_{2}$ can always be supplemented in the core of the nano carrier for photodynamic depletion by the BODIPY inside. Therefore, we can obtain enhanced PDT efficacy in vitro and in vivo which can overcome the limitation of hypoxia microenvironment in tumor areas in the clinical use of PDT

\section{References}

1. Dolmans DE, Fukumura D, Jain RK (2003) Photodynamic therapy for cancer. Nat Rev Cancer 3(5): 380-387.

2. Agostinis P, Berg K, Cengel KA, Foster TH, Girotti AW, et al. (2011) Photodynamic therapy of cancer: an update. CA Cancer J Clin 61: 250281.

3. Celli JP, Spring BQ, Rizvi I, Evans CL, Samkoe KS (2010) Imaging and photodynamic therapy: mechanisms, monitoring, and optimization Chem Rev 110(5): 2795-2838. 
4. Ethirajan M, Chen YH, Joshi P, Pandey RK (2011) The role of porphyrin chemistry in tumor imaging and photodynamic therapy. Chem Soc Rev 40: $340-362$.

5. Ruan Z, Liu L, Jiang W, Li SY, Wang YC, et al. (2017) Biomater Sci-Uk 5: 313-321.

6. Ulrich G, Ziessel R, Harriman A (2008) The chemistry of fluorescent bodipy dyes: versatility unsurpassed. Angew Chem Int Edit 47(7): 1184-1201.

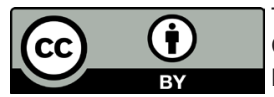

This work is licensed under Creative Commons Attribution 4.0 License

DOI: 10.19080/AJOP.2018.01.555555
7. Ruan Z, Zhao Y, Yuan P, Liu L, Wang Y, et al. (2018) PEG conjugated BODIPY-Br ${ }_{2}$ as macro-photosensitizer for efficient imaging-guided photodynamic therapy. Journal of Materials Chemistry B 5: 753-762.

8. Brown JM, William WR (2004) Exploiting tumour hypoxia in cancer treatment. Nat Rev Cancer 4: 437-447.

9. Yuan P, Ruan Z, Jiang W, Liu L, Dou J, et al. (2018) Oxygen self-sufficient fluorinated polypeptide nanoparticles for NIR imaging-guided enhanced photodynamic therapy. Journal of Materials Chemistry B 15: 2323-2331.

\section{Your next submission with Juniper Publishers} will reach you the below assets

- Quality Editorial service

- Swift Peer Review

- Reprints availability

- E-prints Service

- Manuscript Podcast for convenient understanding

- Global attainment for your research

- Manuscript accessibility in different formats

( Pdf, E-pub, Full Text, Audio)

- Unceasing customer service

Track the below URL for one-step submission https://juniperpublishers.com/online-submission.php 